\title{
PARENTS' BEHAVIOR IN GIVING DRUG IN CHILDREN WITH TUBERCULOSIS IN POLYCLINIC CHILDREN RSUD. DR. PIRNGADI MEDAN
}

\author{
RENI ASMARA ARIGA ${ }^{1 *}$, RINA AMELIA ${ }^{2}$ \\ ${ }^{1}$ Department of Nursing Child, Faculty of Nursing, Universitas Sumatera Utara, Jl. Prof. Maas No. 3, Medan, Indonesia. ${ }^{2}$ Department of \\ Public Health, Faculty of Medicine, Jl. Dr. Mansyur No. 5, Medan, Indonesia. Email: reni.asmara.ariga@usu.ac.id
}

Received: 07 March 2018, Revised and Accepted: 25 March 2018

\section{ABSTRACT}

Objective: Identify the parents behaviour in the provision of drugs in children with tuberculosis in Children Patient at Polyclinic RSUD Dr. Pirngadi Medan (Dr. Pirngadi General Hospital Medan State).

Methods: This study uses descriptive design with the number of samples of 42 respondents. Samples were taken using consecutive sampling technique. The data were collected using a knowledge, attitude, and action questionnaire. The data collected were analyzed using descriptive statistics, then the result of data analysis is presented in frequency distribution table and percentage.

Results: The majority of respondents have good knowledge as much as $85.7 \%$, and the majority of respondents have good attitude of $76.2 \%$ while the majority of respondents have an adequate action of $52.3 \%$.

Conclusion: The behavior of parents in the provision of drugs in children with TBC in good category.

Keywords: Behavior, Parent, Drug, Child, TBC.

(C) 2018 The Authors. Published by Innovare Academic Sciences Pvt Ltd. This is an open access article under the CC BY license (http://creativecommons. org/licenses/by/4. 0/) DOI: http://dx.doi.org/10.22159/ajpcr.2018.v11s1.26617

\section{INTRODUCTION}

Pulmonary tuberculosis (TB) disease or better known as TB is a disease caused by bacteria/bacteria Mycobacterium TB. These germs commonly affect the lungs and some can strike outside the lungs such as lymph nodes, skin, intestines/gastrointestinal tract, cerebral membranes, and so on [1].

Pulmonary TB is an important public health problem in the world. The World Health Organization (WHO) report (2004, in PDPI, 2006) [2] states that there are 8.8 million new cases of pulmonary TB and 3.9 million cases of Basil Tahan Asam positive in 2002. One-third of the world's population has been infected with TB germs and by the WHO the largest number of TB cases occur in Southeast Asia that is 33\% of all TB cases in the world. However, when viewed from the population, there are 182 cases per 100,000 population. In Africa, almost 2 times larger than in Southeast Asia that is 350 every 100,000 population [2].

TB is a major public health problem in Indonesia. The number of patients in Indonesia is the third largest in the world after India and China with patients about $10 \%$ of the total number of TB patients worldwide. It is estimated that in 2004 every year there are 539,000 new cases and 101,000 deaths. The incidence of smear-positive TB cases is about 110 every 100,000 population [3]. According to the WHO, the prevalence of infectious TB in Indonesia is 715,000 cases every year. This disease is also the third leading cause of death after heart disease and respiratory diseases. To overcome this, the Minister of Health of Indonesia on March 24, 1999 proclaimed GERDUNAS TB (National Integrated Movement for TB Eradication). In this program, all parties both private and community governments are invited to cope with this disease [4].

In Children Polyclinic RSUD. Dr. Pirngadi Medan obtained the number of pulmonary TB patients who undergo treatment in January-September 2012 as many as 210 people. The WHO states that the key to the success of the pulmonary TB program is to implement the directly observed treatment short course (DOTS) strategy, which has also been adopted by our country. Therefore, understanding of DOTS is very important for pulmonary $\mathrm{TB}$ can be handled properly. DOTS contains five components, namely: The government's commitment to run a national
TB program; TB case finding with microscopic smear examination; the provision of short-term drugs that are directly supervised; ongoing OAT procurement; monitoring and recording; and reporting of the standard/standard [2].

The guidelines for behavior that nurses should do in the management of pulmonary TB are: Always sputum examination should be performed when symptoms develop an impression of pulmonary TB; it is certain that the patient understands that he or she needs a complete period of treatment even though the symptoms quickly disappear (give the patient a leaflet about treatment when available); provide an explanation to the family about pulmonary TB; and treat patients with hospitality and sympathetic so that patients will be more likely to return to take medication and continue treatment (think of him as a friend you want to help). In addition, it is necessary to conduct a house contact examination, put the patient's name into the TB register and give the treatment card for the date of drug-taking date, make sure the patient understands and remembers it, make a home visit if the patient does not come to take the medicine, and the most important thing is to check the availability of OAT (anti-TB drugs) to avoid the breakup of treatment [3].

Behavior is the totality of appreciation and activity of a person who is the result of the joint between various factors, both internal and external factors, in other words, human behavior is very complex and has a very broad expanse. [4] Human behavior is divided into three categories, namely, cognitive, affective, and psychomotor.

According to PDPI (2006) [2] irregular drug administration, anti-TB drug use long enough, so cause saturation, patient knowledge less about TB disease can cause resistance to drug TB.

In the prevention and control of resistance to the use of TB, drug behavior is needed to support a better change, especially patient behavior. Hence, the authors conducted a study on the behavior of pulmonary TB patients in undergoing treatment at Padang Bulan Puskesmas Medan.

Provision of safe and accurate drugs is one of the most important tasks of the nurse. Drugs are the primary means of therapy that doctors use to 
treat patients who have health problems, even though the drug benefits patients in many ways. Some drugs may cause serious side effects or potentially cause harmful side effects if improperly administered, especially if these drugs are given to pediatric patients for it to be necessary family knowledge about oral administration. Patients who are hospitalized will receive oral medication and this administration continues until the patient returns/leaves the hospital.

Oral drug delivery is the easiest and most commonly used route. Drugs are given by mouth and in swallow. Drugs given orally are cheaper than many other preparations. Onset of oral drug action is slower and the effect is longer. Clients generally prefer the oral route.

The nurse should assess the ability of the patient or his family to prepare the dosage and use the drug properly. If the client is unable to use the drug independently, the nurse can learn whether any family member or friend can help.

\section{MATERIALS AND METHODS}

Research design is the whole process required in planning and conducting research. The type of research that will be conducted is descriptive to know the family knowledge about drug administration.

The population in the study was parents whose children suffered from TB at Polyclinic RSUD. Dr. Pirngadi Medan which amounted to 210 people. Samples can be taken $10-25 \%$ of the total population. Hence, the number of samples in this study was 42 people with the following sample criteria: Parents who have children who suffer from TB who seek treatment at the Polyclinic RSUD. Dr. Pirngadi Medan, able to read and write, willing to be a respondent

The sampling technique is consecutive sampling, i.e., all the subjects that exist and meet the selection criteria included in the measurement.

The research was conducted at Polyclinic RSUD. Dr. Pirngadi Medan. The reason for taking the location is because in RSUD. Dr. Pirngadi Medan there is sufficient number of population and sample and in accordance with the inclusion criteria from the research. Research activities have been conducted in October 2012.

\section{RESULTS}

From the results of research that has been carried out obtained the following characteristics of respondents, most respondents $42.9 \%$ are in the age range of 36-46 years. The majority of respondents' occupation is civil servant that is equal to $76.2 \%$ with education level of majority respondent of university that is equal to $61.9 \%$ and majority do not have a history of family member who have suffered from pulmonary TB disease. For more clearly can be shown in Table 1 .

Assessment of parental behavior in giving of drug to children with TB by summing percentage of knowledge, attitude, and action then divided by three indicate that majority of respondents have good behavior equal to $57.1 \%$, behavior is enough equal to $30.1 \%$, and behavior less $12.8 \%$

The results of research on the percentage of behavior can be seen in Table 2 .

Assessment of parental behavioral knowledge in drug delivery in children with TB is done using questionnaires in the form of statements with correct and false answers. The results of knowledge assessment can be seen the level of knowledge of parents in the provision of drugs in children with TB in Children Polyclinic RSUD. Dr. Pirngadi Medan divided into two levels. The result showed that 36 respondents $(85.7 \%)$ had good knowledge level and 6 respondents $(14.3 \%)$ had less knowledge level. For more clearly can be shown in Table 3.

Assessment of parental attitudes in drug delivery in children with TB was done using a questionnaire in the form of Likert scale with the choice of answers strongly agree, agree, and disagree. The results are divided into three categories of attitude that is good, medium, and less indicate that the majority of respondents have good attitude of 32 respondents (76.2\%), attitude enough 10 respondents $(23.8 \%)$, and none have less attitude.

For more clearly can be shown in Table 4 .

Assessment of parental action in drug delivery in children with TB was done using a questionnaire in the Likert scale, with the choice of answers always, often, occasionally, and never. From the result Table 4, 22 respondents (52.3\%) have enough action, 4 respondents (9.5\%) have good action, and 16 respondents (38.2\%) have less action. For more clearly can be shown in Table 5 .

\section{DISCUSSION}

Changes in behavior can occur after a person knows the stimulus or object such as health, then make an assessment or opinion of what is

Table 1: Characteristics of respondents

\begin{tabular}{|c|c|c|}
\hline No & Characteristics of respondents & Frequency (\%) \\
\hline \multirow[t]{5}{*}{1} & Age (years) & \\
\hline & $25-35$ & $12(28.5)$ \\
\hline & $36-46$ & $18(42.9)$ \\
\hline & $47-57$ & $10(23.9)$ \\
\hline & $>57$ & $2(4.7)$ \\
\hline \multirow[t]{6}{*}{2} & Level of education & \\
\hline & Primary school & $4(9.5)$ \\
\hline & Junior high school & $2(4.8)$ \\
\hline & Senior high school & $10(23.8)$ \\
\hline & College & $26(61.9)$ \\
\hline & Pekerjaan & \\
\hline \multirow[t]{3}{*}{3} & Housewife & 14.3 \\
\hline & Enterpriser & 9.5 \\
\hline & Government employees & 76.2 \\
\hline
\end{tabular}

Table 2: Behavior of pulmonary TB patients

\begin{tabular}{lll}
\hline No & Behavior of pulmonary TB patients & Percentage \\
\hline 1 & Good & \\
\hline 2 & Sufficient & 57.1 \\
3 & Deficient & 30.1 \\
& Amount & 12.8 \\
\hline
\end{tabular}

Table 3: Level of knowledge

\begin{tabular}{lll}
\hline No & Level of knowledge & Frequency (\%) \\
\hline 1 & Good & $36(85.7)$ \\
2 & Sufficient & $6(14.3)$ \\
& Amount & $42(100)$ \\
\hline
\end{tabular}

Table 4: Assessment of attitude

\begin{tabular}{lll}
\hline No & Assessment of attitude & Frequency (\%) \\
\hline 1 & Good & $32(76.2)$ \\
2 & Sufficient & $10(23.8)$ \\
3 & Deficient & $0(0)$ \\
& Amount & $42(100)$ \\
\hline
\end{tabular}

Table 5: Action

\begin{tabular}{lll}
\hline No & Action & Frequency (\%) \\
\hline 1 & Good & $4(9.5)$ \\
2 & Sufficient & $22(52.3)$ \\
3 & Deficient & $16(38.2)$ \\
& Amount & $42(100)$ \\
\hline
\end{tabular}


known, the next process is expected that someone will implement or practice what is known and responded.

From the results of research that has been done that the behavior of parents in the provision of drugs in children with TB more than half of respondents $(57.1 \%)$ have good behavior. This means that the behavior of parents in the provision of drugs in children with TB is good.

The good behavior of parents in giving medicine to children with TB is most likely influenced by knowledge, where the knowledge of the respondents is good $85.7 \%$, good respondent attitude equal to $76.2 \%$, and supported by respondent action enough equal to $52.3 \%$. Knowledge is the result of knowing and this happens after people have sensed certain objects [5]. Knowledge of a new object becomes an attitude when knowledge is accompanied by readiness to act in accordance with knowledge of the object [6]. In this study, the studied knowledge is about the treatment of pulmonary TB which includes the type of drug, sputum examination, duration of treatment, medical history, and the presence of drug swallowing (PMO).

From the research that has been done that the respondents of parents in the provision of drugs in children with TB have a good knowledge level of $85.7 \%$, this can be influenced by the age and level of education of the respondent. Judging from the average age of respondents is in the range of early adult age. Early adulthood is known as the creative period in which individuals have the mental ability to learn and adapt to new situations such as remembering what has been learned, analogical reasoning, creative thinking, and memory loss [7-9].

The level of education that can affect knowledge in accordance with the opinion [4] said that knowledge is influenced by many factors such as education, experience, motivation, information sources, socioeconomic, perceptions, and culture. In terms of education, the majority of respondents are $61.9 \%$ of university graduates. The knowledge of pulmonary TB patients is better than the knowledge of patients with pulmonary TB in Pagak Regency Malang working area conducted by that $77.9 \%$ of respondents have sufficient knowledge about pulmonary TB disease, this may be due to different instruments statement which are given [10].

However, when viewed in detail from each statement, there are still some statements where the level of ignorance of respondents about sputum examination in patients with pulmonary TB performed 2 days reached $57.8 \%$ and this can cause sputum examination to be inaccurate resulting pulmonary TB diagnosis is not appropriate. This is caused in addition to the lack of knowledge of respondents also because the distance of puskesmas with home far. It is seen that $68.9 \%$ of people with TB paru not yet know that one of the preventions of TB disease can be done by giving BCG immunization. According to, one of the preventions of pulmonary TB is by doing BCG vaccination. $80 \%$ effective BCG vaccination can prevent for 15 years [11]

For statements of pulmonary TB patients who were dropping out for 2 months or more with positive smear was discontinued after treatment as much as $62.2 \%$ respondents answered wrong. This may cause that treatment to be incomplete because people with pulmonary TB think that stopping treatment for 2 months or more will not have a severe impact on the disease. Meanwhile, according to said the drop of treatment can cause TB germs can become resistant to the drug so that requires treatment category 2 [12].

Attitude is a person's assessment of the stimulus or object (in this case is a health problem, including disease). Attitude indicators are in line with knowledge, namely, attitude toward illness and disease, attitude of way of maintenance and healthy way of life, and attitude toward environmental health [4].

The result showed that $76.2 \%$ showed good attitude toward parents in giving medicine to children with TB, as many as $24.4 \%$ showed sufficient attitude in lung TB patients to undergo treatment, and there was no less attitude in lung TB patients in undergoing treatment. Overall, attitudes of parents in the provision of drugs in children with TB have a good attitude of $76.2 \%$. This good attitude needs to be developed because it will affect the behavior change of pulmonary TB patients in undergoing treatment so that treatment can be done thoroughly and there is no failure in treatment.

Based on the assessment of the answers given by the respondents that all statements are more well responded. However, when viewed in detail from each statement, there are still respondents respond poorly even though the percentage is only a little that is on the statement to prevent transmission of pulmonary TB by not throwing sputum haphazardly, the statement opening the window in the morning and let incoming sunlight can prevent transmission of TB lung and the statement of pulmonary TB treatment is completed within the stipulated time (6-9 months).

Based on the research seen $5.3 \%$ of respondents did not agree that the prevention of transmission of pulmonary TB can be done by not throwing sputum indiscriminately, it is most likely the respondents consider that sputum did not cause transmission of pulmonary TB while according to PDPI (2006) [2]. TB contagious at the time of speech, sneezing, or coughing. Pulmonary TB sufferers will remove the TB germs that exist in his lungs into the air in the form of sputum splashes. Then, unwittingly they are smear positive, and unintentionally, others will breathe air containing the TB germ into the lungs and then spread to other body parts.

The results of research on the statement opening the window in the morning and let incoming sunlight can prevent transmission of pulmonary TB got $4 \%$ answered less agree and $1.3 \%$ answered disagree. According to, prevention of pulmonary TB can be done using direct sunlight so it can kill the germs of TB lung. Transmission in dark homes is more susceptible than sunlight-infested homes, especially in the tropics [11].

In statements about pulmonary TB treatment, $6.7 \%$ of respondents disagreed that pulmonary TB treatment was completed within the prescribed time (6-9 months). According to PDPI (2006) [2], unfinished use of OAT can lead to the resistance of TB to lung TB to OAT. The administration of irregular drugs, for example, is only eaten 2-3 weeks and then stops, after 2 months of stopping, then switching doctors and taking medication again for 2 or 3 months then stop again, and so can also cause TB lung resistance to OAT.

When associated with theory in Aswar (2005) [8], the level of knowledge is a predisposing factor in obtaining a good attitude because every individual has a motive to want to know, want to understand, and gain much experience and knowledge. In the results of this study shows the level of knowledge of patients with TB lung in the treatment of $84.4 \%$ has a good level of knowledge and this result is very related to the good attitude also owned by respondents of $75.6 \%$.

Action is a rule done in the conduct/conduct rules to overcome something or the act of a close relationship between attitudes and actions supported by the notion of attitude that states that attitude is a tendency to act [5].

The work is also very influential on the action in undergoing pulmonary TB treatment where $62.2 \%$ of respondents are entrepreneurs (traders) who generally go early in the morning even evening until the evening so the respondents did not have time to follow the counseling about pulmonary TB.

Based on the results of the study of $37.3 \%$ of respondents never follow health counseling about pulmonary $\mathrm{TB}$, this can affect the action of TB patients in undergoing treatment. Meanwhile, according to, follow health education or health education can change the behavior of individuals in living a healthy life [13]. 
In the Statement I covered my mouth with a handkerchief if coughing and sneezing as much as $25.3 \%$ never covered my mouth with a handkerchief if coughing and sneezing as well as in Statement III (I throw sputum in place to prevent transmission of pulmonary TB) by $26.7 \%$ of respondents never throw sputum in place to prevent transmission of pulmonary TB. Meanwhile, according to PDPI (2006) [2], TB is contagious when talking, spitting, sneezing, or coughing. Pulmonary TB sufferers will remove the TB germs that exist in his lungs into the air in the form of sputum splashes. Then, unwittingly they are smear positive, and accidentally, others will breathe the air containing the TB germ into the lungs and then spread to other body parts, so closing the mouth is very important in the prevention of transmission of pulmonary TB.

In the Statement I consume a healthy and nutritious food to prevent the occurrence of pulmonary TB results obtained as much as $44 \%$ of respondents answered sometimes in terms of eating healthy and nutritious foods to prevent the occurrence of pulmonary TB. This is directly proportional to the body mass index of the majority of respondents who have a thin body of $42.2 \%$. It can also be influenced by economic factors of respondents with the majority of employment is self-employed by $62.2 \%$. According to, nutritional status is quite a very important factor in the prevention of pulmonary TB disease and improvement of health status in adults and children [11].

\section{CONCLUSION}

Based on the results of research that has been conducted in October 2012 in Children Polyclinic RSUD. Dr. Pirngadi Medan about the behavior of parents in the provision of drugs in children with TB where behavior consists of knowledge, attitudes, and actions. Overall, the behavior of parents in the provision of drugs in children with TBC in good category of $57.1 \%$, sufficient category of $30.1 \%$, and category $<12.8 \%$ with details as follows: Knowledge of pulmonary TB patients in overall treatment good of $85.7 \%$. The attitude of pulmonary TB patients in overall treatment has a good attitude of $76.2 \%$. The action of pulmonary TB patients in overall treatment has an adequate action of $52.3 \%$.

\section{Suggestion}

1. The results of this study should be used as a reference for community nurses in providing health education and monitoring of treatment for patients with pulmonary TB in treatment.

2. From the results of this study is expected to be additional information for nursing students to share knowledge and experience in improving service quality and improve nursing education in handling the behavior of patients with pulmonary TB who undergo treatment at the hospital.

3. From the results of the study found that the behavior of parents in the provision of drugs in children with TB in which the results obtained good knowledge of $85.7 \%$, good attitude of $76.2 \%$, and adequate action of $52.3 \%$. So for further research is expected to complete this research by looking for factors that influence the knowledge and attitude of patients with pulmonary TB in undergoing treatment and make observations on the behavior of patients with pulmonary TB in undergoing treatment. The next researcher is expected to pay attention to this research instrument to be tested again.

4. Although in this research obtained good knowledge equal to $85.7 \%$, good attitude equal to $76.2 \%$, and enough action equal to $52.3 \%$, hospital expected more can improve service quality by giving health education, especially in monitoring of patient of TB lung in the treatment.

\section{REFERENCES}

1. Laban YY. TBC Penyakit and Cara Pencegahannya. $5^{\text {th }}$ ed. Yogyakarta: Kanisius; 2008. p. 7.

2. Perhimpunan Dokter Paru Indonesia. Pedoman Diagnosis dan Penatalaksaan di Indonesia. $1^{\text {st }}$ ed. Jakarta: Rineka Cipta; 2006. p. 2.

3. Departemen Kesehatan Republik Indonesia. Penanggulangan Tuberkulosis. $2^{\text {nd }}$ ed. Jakarta: Departemen Kesehatan Republik Indonesia; 2008 .

4. Horne C. Tuberkulosis Klinis. $2^{\text {nd }}$ ed. Miller. Jakarta: Widya Medika; 2002.

5. Notoatmojo S. Metodologi Penelitian Kesehatan. $3^{\text {rd }}$ ed. Jakarta: Rineka Cipta; 2007.

6. Notoatmojo S. Promosi Kesehatan dan Ilmu Perilaku. $2^{\text {nd }}$ ed. Jakarta: Rineka Cipta; 2003.

7. Purwanto H. Pengantar Perilaku Manusia Untuk Keperawatan. $1^{\text {st }}$ ed. Jakarta: EGC; 1999.

8. Hurlock BE. Psikologi Perkembangan. $5^{\text {th }}$ ed. Jakarta: Erlangga; 1999.

9. Aswar S. Sikap Manusia Teori dan Pengukurannya. $2^{\text {nd }}$ ed. Yogyakarta: Pustaka Belajar; 2005.

10. Riswan R, Nuraeni R. Hubungan Pengetahuan tentang Tuberkulosis (TB) dengan Tingkat Kecemasan pada Pasien TB Paru di RSUD CIDERES Kabupaten Majalengka Tahun 2015. J Keperawatan Kesehatan Medisina AkPer YPIB Majalengka 2015;1:1-10.

11. Crofton J, Horno N, Miller F. Tuberkulosis Klinis. Jakarta: Widya Medika; 2002.

12. Dyah RW, Yani JS. Diabetes Melitus dan Permasalahannya pada Infeksi Tuberkulosis. J Respir Indo 2013;33:126-34.

13. Nurhidayah I, Noviyani I, Fatimah S, Adistie F. Upaya Pencegahan Penularan TB dari Dewasa terhadap Anak. J Keperawatan Padjajaran 2015;3:97-103. 